\title{
To study the effect of level of jaggery and sapota pulp on chemical quality of Kulfi
}

\author{
P.J. UBALE, A.S. HEMBADE AND D.M. CHOUDHARI
}

\begin{abstract}
The three levels of pulp of sapota 16, 25 and 40 per cent were used with three levels of jaggery i.e. 7, 8 and 9 per cent to prepare the Kulfi. In conclusion the protein and fat content decreased with increase in levels of jaggery and fruit pulp in end product i.e. Kulfi and the non-reducing sugar, reducing sugar, iron, ash, total solids contents ware increased in end product with increase in levels of both i.e. jaggery and fruit pulp.
\end{abstract}

KEY WORDS : Milk, Sapota, Jaggary, Kulfi

How to CITE THIS PAPER : Ubale, P.J., Hembade, A.S. and Choudhari, D.M. (2014). To study the effect of level of jaggery and sapota pulp on chemical quality of Kulfi. Res. J. Animal Hus. \& Dairy Sci., 5(2) : 62-67.

Address for correspondence :

P.J. Ubale, Sangamner Taluka Dudhutpadak Sangh Ltd., Rajhans Dairy, Sangamner, AHMEDNAGAR (M.S.) INDIA

Email : balrajdairy_2007@rediffmail.com

Associated Authors' :

A.S. Hembade, Department of Dairy Science, Yeshwant Mahavidyalaya, NANDED (M.S.) INDIA

D.M. Choudhari, Section of Animal Science and Dairy Science, Shramshakti College of Agriculture, Sangamner, AHMEDNAGAR (M.S.) INDIA 